Article

\title{
Endocrine Disruptors and Obesity: An Examination of Selected Persistent Organic Pollutants in the NHANES 1999-2002 Data
}

\author{
Mai A. Elobeid ${ }^{1,2}$, Miguel A. Padilla ${ }^{3,4}$, David W. Brock ${ }^{2}$, Douglas M. Ruden ${ }^{5}$, \\ and David B. Allison ${ }^{1,6,7}, *$
}

1 Department of Biostatistics, University of Alabama at Birmingham, 1665 University Boulevard, Birmingham, AL, USA, 35294; E-Mail: maielobeid@gmail.com

2 Division of Cardiovascular Disease, Department of Medicine, University of Alabama at Birmingham, 1665 University Boulevard, Birmingham, AL 35294, USA;

E-Mail: David.Brock@uvm.edu

3 Department of Psychology, Old Dominion University, 250 Mills Godwin Building, Norfolk, VA 23529, USA; E-Mail: mapadill@odu.edu

4 Department of Mathematics and Statistics, Old Dominion University, 250 Mills Godwin Building, Norfolk, VA 23529, USA

5 Institute of Environmental Health Sciences, Wayne State University, 259 Mack Avenue, Detroit, MI 48201, USA; E-Mail: douglasr@wayne.edu

6 Department of Nutrition Sciences, University of Alabama at Birmingham, 1665 University Boulevard, Birmingham, AL 35294, USA

7 Clinical Nutrition Research Center, University of Alabama at Birmingham, 1665 University Boulevard, Birmingham, AL 35294, USA

* Author to whom correspondence should be addressed; E-Mail: Dallison@uab.edu; Tel.: +1-205-975-9169; Fax: +1-205-975-2540.

Received: 16 June 2010; in revised form: 16 July 2010 / Accepted: 19 July 2010 / Published: 23 July 2010

\footnotetext{
Abstract: Recent evidence suggests that endocrine disrupting chemicals (EDCs) may cause perturbations in endogenous hormonal regulation that predispose to weight gain. Using data from NHANES (1999-2002), we investigated the association between body mass index (BMI), waist circumference (WC) and selected persistent organic pollutants (POPs) via multiple linear regressions. Consistent interaction was found between gender, In oxychlordane and ln p,p' DDT. Also, we found an association between WC and ln
} 
oxychlordane and ln hpcdd in subjects with detectable levels of POPs, whereas an association between WC and ln p,p’ DDT was observed in all subjects. Furthermore, ln Ocdd showed an increase with higher WC and BMI, whereas, ln trans-nonachlor decreased with higher BMI. Hence, BMI and WC are associated with POPs levels, making the chemicals plausible contributors to the obesity epidemic.

Keywords: obesity; endocrine disruptors; waist circumference; persistent organic pollutants; public health

\section{Introduction}

The prevalence of obesity has risen substantially in both adults and children, and is recognized as a serious public health problem [1]. Beyond body mass index (BMI) $\mathrm{Kg} / \mathrm{m}^{2}$, which is the most commonly used proxy index of obesity, indicators of regional fat distribution such as waist circumference (WC) have been linked to cardiovascular disease [2-6], insulin resistance syndrome [7-10], and increased risks of breast, colorectal, and renal cancer [11-13]. A recent study showed small but consistent increases in WC in the U.S. population over calendar time from the 1960s to the present even when measured at any fixed BMI level [14].

While much has been written about the reasons behind the global obesity epidemic, industrial toxicants found in the environment, the food system, and humans have just begun to receive significant attention. Recent evidence suggests that environmental contaminants known or presumed to disrupt endocrine systems, appropriately termed endocrine disrupting chemicals (EDCs), may play a role in the growing problem of obesity $[15,16]$. These contaminants are mostly persistent in the environment and are known as persistent organic pollutants (POPs). It is plausible that POPs lead to preferential increases in abdominal fat because it is known that the hormonal milieu has profound effects on the anatomic distribution of fat. However, whether associations between lifetime exposure to low doses of a mixture of various POPs and measures of adiposity exist in the general population is not known. Given that almost all persons are exposed to POPs, the public health importance of a relation of these chemicals with weight gain may be substantial, despite a relatively modest association with any individual POPs.

Recently, a dose-response relation was observed between serum concentrations of POPs and metabolic syndrome [17], insulin resistance [18], and diabetes [19]. Surprisingly, in people with undetectable levels of POPs, the typically robust association between obesity and diabetes was not observed [19]. However, an unanswered question is whether POPs might directly contribute to obesity in the population. Lee and colleagues have offered some useful evidence, but their study only treated BMI and WC as covariates, not as outcomes to be modeled. Hence, to explore this possibility of POPs' associations with adiposity indicators, we investigated the associations among BMI, WC and selected POPs,-which do not have high affinities for the Aryl hydrocarbon receptor (Ahr)-, in 1999-2002 data from the National Health and Nutrition Examination Survey (NHANES 99-02). Some of the examined POPs are dioxins, which are a family of chlorinated hydrocarbon compounds known chemically as dibenzo-p-dioxins. Dioxins are highly toxic and persist in the environment for extended periods. They 
are produced during incineration of wastes and are produced as contaminants in chemical manufacturing processes [20]. We examined the measured POPs in that dataset which are 1,2,3,4,6,7,8-heptachlorodibenzo-p-dioxin (hpcdd), 1,2,3,4,6,7,8,9-octachlorodibenzo- $p$-dioxin (Ocdd), oxychlordane, trans-nonchlor, and $p, p^{\prime}$-DDT. The POPs that have higher affinities for the Ahr in the NHANES dataset, such as 2,3,7,8-tetrachlorodibenzo-p-dioxin (TCDD), did not show significant associations with either BMI or WC.

\section{Experimental Section}

\subsection{Sample}

We used data from the publicly available nationally representative cross-sectional surveys of the U.S. non-institutionalized civilian population conducted by the US National Center for Health and Statistics (NCHS), (NHANES 1999-2000, 2001-2002). These surveys have the same basic structure and plan, and they both contain data on age, gender, race, height, weight, and WC.

\subsection{Measures}

Anthropometric measures including height, weight, and WC were obtained via standardized protocols as described elsewhere (http://www.cdc.gov/nchs/data/nhanes/frequency/bmxdoc.pdf).

Measures of polychlorinated dibenzo-p-dioxins (PCDDs), dobenzofurans (PCDFs), and non-ortho substituted or coplanar polychlorinated biphenyls (cPCBs), other polychlorinated biphenyls (PCBs), persistent chlorinated metabolites were assessed in participants on a one-third serum samples. For this analysis, data from the two surveys (1999-2000 and 2001-2002) were aggregated. The NHANES standardized home interview was followed by a detailed physical examination in a mobile evaluation clinic or the participant's home. PCDDs, PCDFs, PCBs, and organochlorine pesticides were all measured in serum samples as individual chemicals by high resolution gas chromatography mass spectrometry (GC-MS) using isotope dilution for quantification. The POPs were provided by NHANES and adjusted for serum total cholesterol and triglycerides. All POPs levels were transformed by taking the natural log (ln) of each in order to improve linearity and analyzed in their transformed form.

We selected five POPs (present in 80\% of the NHANES population): 1,2,3,4,6,7,8-heptachlorodibenzo-pdioxin (hpcdd); 1,2,3,4,6,7,8,9-octachlorodibenzo-p-dioxin (Ocdd); oxychlordane; trans-nonchlor, and p,p'-DDT. Based on the above criteria, a total of 2,464 participants with valid BMI scores and 2,448 participants with valid WC score were examined.

\subsection{Statistical Analysis}

The primary analysis used three regression models to test all available participants for associations with overall adiposity as assessed by BMI and WC. Two models regressed BMI and WC on gender, ethnicity, age, age squared, and POPs. The third model regressed WC on the previous predictors while controlling for BMI. We will refer to these models as additive models. Each of these models was extended by including two-way interactions between gender and the POPs. Secondary/sensitivity analyses employed all of the same models as the primary analyses but evaluated only participants with 
detectable levels of POPs. All parameter interpretations will be done on using standard deviation units based on standardized regression parameters; $b_{j}=\hat{\beta}_{j}\left(S_{j} / S_{y}\right)$.

All analyses, including descriptive statistics, were conducted using SAS-Callable SUDDAN 9.0.1, which estimates standard errors using the sampling weights, strata, and primary sampling units (PSU) from NHANES taking into account for the complex sampling procedures used. For details on the sampling procedures used, visit the NHANES website at http://www.cdc.gov/nchs/nhanes.htm.

\section{Results and Discussion}

\subsection{Descriptive Statistics}

Descriptive statistics for gender, ethnicity, age, BMI, and WC are displayed in Table 1.

Table 1. Descriptive statistics for detectable persistent organic pollutants.

\begin{tabular}{|c|c|c|c|c|c|c|}
\hline & \multicolumn{3}{|c|}{ BMI } & \multicolumn{3}{|c|}{ Waist Circumference } \\
\hline & $\mathrm{n}$ & Mean & $95 \%$ CI & $\mathrm{n}$ & Mean & $95 \%$ CI \\
\hline$\underline{\text { Gender }}$ & & & & & & \\
\hline Male & 1,140 & $\begin{array}{l}27.75 \\
(0.28)\end{array}$ & $27.17,28.33$ & 1,133 & $\begin{array}{l}98.53 \\
(0.72)\end{array}$ & $97.07,100.00$ \\
\hline Female & 1,324 & $\begin{array}{l}27.55 \\
(0.26)\end{array}$ & 27.01, 28.09 & 1,315 & $\begin{array}{l}91.82 \\
(0.80)\end{array}$ & $90.19,93.46$ \\
\hline Ethnicity & & & & & & \\
\hline Mexican American & 758 & $\begin{array}{l}27.77 \\
(0.27)\end{array}$ & $27.22,28.33$ & 749 & $\begin{array}{l}92.94 \\
(0.61)\end{array}$ & $91.69,94.19$ \\
\hline Non-Hispanic Black & 112 & $\begin{array}{l}28.09 \\
(0.83)\end{array}$ & 26.39, 29.79 & 112 & $\begin{array}{l}95.19 \\
(2.67)\end{array}$ & $89.72,100.66$ \\
\hline Non-Hispanic White & 1,022 & $\begin{array}{l}27.47 \\
(0.28)\end{array}$ & $26.90,28.04$ & 1,026 & $\begin{array}{l}95.49 \\
(0.80)\end{array}$ & 93.85, 97.14 \\
\hline Other Hispanic & 485 & $\begin{array}{l}28.91 \\
(0.37)\end{array}$ & 28.15, 29.68 & 475 & $\begin{array}{l}94.92 \\
(1.03)\end{array}$ & 92.82, 97.02 \\
\hline Other Race & 87 & $\begin{array}{l}26.71 \\
(0.68)\end{array}$ & $25.32,28.10$ & 86 & $\begin{array}{l}90.34 \\
(1.95)\end{array}$ & 86.34, 94.33 \\
\hline Age & & & & & & \\
\hline 06-18 yrs & 504 & $\begin{array}{l}23.17 \\
(0.32)\end{array}$ & 22.52, 23.82 & 500 & $\begin{array}{l}80.52 \\
(0.81)\end{array}$ & 78.86, 82.18 \\
\hline $19-28$ yrs & 397 & $\begin{array}{l}26.71 \\
(0.44)\end{array}$ & $25.81,27.60$ & 391 & $\begin{array}{l}90.60 \\
(1.23)\end{array}$ & 88.08, 93.12 \\
\hline $29-39$ yrs & 369 & $\begin{array}{l}27.84 \\
(0.49)\end{array}$ & 26.84, 28.84 & 367 & $\begin{array}{l}93.64 \\
(1.45)\end{array}$ & $90.68,96.60$ \\
\hline $40+$ yrs & 1,194 & $\begin{array}{l}28.42 \\
(0.24)\end{array}$ & $27.92,28.91$ & 1,190 & $\begin{array}{l}98.49 \\
(0.70)\end{array}$ & $97.07,99.92$ \\
\hline
\end{tabular}

Note. Numbers in parentheses are standard errors of the mean. 


\subsection{Primary Analysis}

\subsubsection{Additive Models}

Results of the additive regression models for all participants are presented in Table 2 . In the additive BMI model there are significant main associations for ethnicity $(\mathrm{p}=0.0466)$, age ( $p<0.00005)$, age squared ( $p<0.00005)$, ln Ocdd ( $p=0.0099)$, and $\ln$ DDT ( $p=0.0353)$, with the overall model accounting for $8 \%$ of the BMI variance. Natural log (ln) values for the POPs were used, as is typical in this type of study [19]. Expressed in standard deviation (SD) units, each 1 SD increase in ln Ocdd, BMI is associated with an increase of 0.249 BMI units and every SD unit increase in In DDT is associated with a BMI increase of 0.106 units (i.e., the Beta value for $\ln$ DDT $=0.48$; Table 2). The joint test p-value for the additive BMI model, which is the simultaneous test of all 5 POPs, is 0.0001 . Additionally, the POPs accounted for $2 \%$ of the BMI variance.

Table 2. Additive regression models for all participants.

\begin{tabular}{|c|c|c|c|c|c|c|}
\hline \multirow[b]{2}{*}{ Variable } & \multicolumn{2}{|c|}{$\mathrm{BMI}$} & \multicolumn{2}{|c|}{ WC } & \multicolumn{2}{|c|}{ WC|BMI } \\
\hline & Beta & p-value & Beta & p-value & Beta & p-value \\
\hline Intercept & $\begin{array}{l}13.26 \\
(2.83)\end{array}$ & 0.0001 & $\begin{array}{l}51.75 \\
(7.43)\end{array}$ & $<0.00005$ & $\begin{array}{c}7.46 \\
(4.15)\end{array}$ & 0.0827 \\
\hline Mexican American & $\begin{array}{c}0.69 \\
(0.86)\end{array}$ & 0.4263 & $\begin{array}{c}1.04 \\
(2.37)\end{array}$ & 0.6629 & $\begin{array}{l}-0.58 \\
(0.77)\end{array}$ & 0.4590 \\
\hline Other Hispanic & $\begin{array}{c}1.27 \\
(1.08)\end{array}$ & 0.2518 & $\begin{array}{c}3.42 \\
(3.30)\end{array}$ & 0.33088 & $\begin{array}{l}-0.12 \\
(1.00)\end{array}$ & 0.9028 \\
\hline White & $\begin{array}{c}0.38 \\
(0.82)\end{array}$ & 0.6442 & $\begin{array}{c}2.16 \\
(2.43)\end{array}$ & 0.3815 & $\begin{array}{c}1.56 \\
(0.92)\end{array}$ & 0.0982 \\
\hline African American & $\begin{array}{c}1.89 \\
(0.91)\end{array}$ & 0.0466 & $\begin{array}{c}2.93 \\
(2.46)\end{array}$ & 0.2431 & $\begin{array}{l}-1.28 \\
(0.90)\end{array}$ & 0.1688 \\
\hline Male & $\begin{array}{c}0.63 \\
(0.39)\end{array}$ & 0.1192 & $\begin{array}{c}8.01 \\
(1.05)\end{array}$ & $<0.00005$ & $\begin{array}{c}6.40 \\
(0.37)\end{array}$ & $<.00005$ \\
\hline Age & $\begin{array}{c}0.33 \\
(0.04)\end{array}$ & $<0.00005$ & $\begin{array}{c}0.89 \\
(0.10)\end{array}$ & $<0.00005$ & $\begin{array}{c}0.11 \\
(0.04)\end{array}$ & 0.0056 \\
\hline Age-2 & $\begin{array}{c}-0.00 \\
(0.005)\end{array}$ & $<0.00005$ & $\begin{array}{c}-0.01 \\
(0.005)\end{array}$ & $<0.00005$ & $\begin{array}{c}0.00 \\
(0.005)\end{array}$ & 0.6518 \\
\hline BMI & . & . & $\cdot$ & . & $\begin{array}{c}3.33 \\
(0.20)\end{array}$ & $<0.00005$ \\
\hline BMI-2 & . & . & . & . & $\begin{array}{c}-0.02 \\
(0.005)\end{array}$ & $<0.00005$ \\
\hline $\ln ($ hpcdd) & $\begin{array}{c}0.44 \\
(0.29)\end{array}$ & 0.1370 & $\begin{array}{c}0.24 \\
(0.74)\end{array}$ & 0.7476 & $\begin{array}{l}-0.68 \\
(0.24)\end{array}$ & 0.0091 \\
\hline $\ln ($ Ocdd $)$ & $\begin{array}{c}0.83 \\
(0.30) \\
\end{array}$ & 0.0099 & $\begin{array}{c}2.31 \\
(0.76) \\
\end{array}$ & 0.0052 & $\begin{array}{c}0.31 \\
(0.25) \\
\end{array}$ & 0.2184 \\
\hline
\end{tabular}


Table 2. Cont.

\begin{tabular}{|c|c|c|c|c|c|c|}
\hline $\ln$ (oxychlordane) & $\begin{array}{c}0.58 \\
(0.64)\end{array}$ & 0.3716 & $\begin{array}{c}1.59 \\
(1.63)\end{array}$ & 0.3359 & $\begin{array}{c}0.16 \\
(0.48)\end{array}$ & 0.7404 \\
\hline $\ln$ (trans-nonachlor) & $\begin{array}{l}-0.74 \\
(0.60)\end{array}$ & 0.2258 & $\begin{array}{l}-1.72 \\
(1.52)\end{array}$ & 0.2697 & $\begin{array}{c}0.04 \\
(0.33)\end{array}$ & 0.9047 \\
\hline $\ln (\mathrm{DDT})$ & $\begin{array}{c}0.48 \\
(0.22)\end{array}$ & 0.0353 & $\begin{array}{c}0.81 \\
(0.52)\end{array}$ & 0.1283 & $\begin{array}{l}-0.17 \\
(0.22)\end{array}$ & 0.4610 \\
\hline Joint Test p-value & \multicolumn{2}{|c|}{0.0001} & \multicolumn{2}{|c|}{0.0008} & \multicolumn{2}{|c|}{0.0798} \\
\hline R-Squared & \multicolumn{2}{|c|}{0.0793} & \multicolumn{2}{|c|}{0.1579} & \multicolumn{2}{|c|}{0.8762} \\
\hline R-Squared (No POPs) & \multicolumn{2}{|c|}{0.0591} & \multicolumn{2}{|c|}{0.1449} & \multicolumn{2}{|c|}{0.8756} \\
\hline $\mathrm{N}$ & \multicolumn{2}{|c|}{2,464} & \multicolumn{2}{|c|}{2,448} & \multicolumn{2}{|c|}{2,428} \\
\hline
\end{tabular}

Note. WC stands for waist circumference. Numbers in parentheses are standard errors. Joint Test refers to the simultaneous test of all POPs.

For the additive WC model, there are significant associations for gender $(\mathrm{p}<0.00005)$, age ( $p<0.00005)$, age squared ( $p<0.00005)$, and $\ln$ Ocdd $(\mathrm{p}=0.0052)$. The model accounted for $16 \%$ of the variance in WC. WC increases by 1.76 centimeters with each SD unit increase in ln Ocdd. The joint test p-value for the additive WC model is 0.0008 .

For testing the additive WC model controlling for BMI, there was a significant association for gender $(\mathrm{p}<0.00005)$ and $\ln$ hpcdd $(\mathrm{p}=0.0091)$ with the model accounting for $88 \%$ of the WC variance (Table 2). In this model, males tended to have 6.40 centimeters higher WC than females. However, WC decreased by 0.163 centimeters for every SD unit increase in ln hpcdd. This is an exception to the general observation that WC increases with POPs exposure. The joint test p-value for testing the POPs simultaneously for the additive WC model controlling for BMI is 0.0798, which is nearly statistically significant.

\subsubsection{Interaction Models}

Table 3 displays the results of the interaction regression models for all participants, and Table 4 displays the interaction regression equations for males and females. The interaction BMI model accounted for $10 \%$ of the variance and showed significant associations for $\ln$ Ocdd $(\mathrm{p}=0.0091)$ and $\ln$ DDT ( $p=0.0020)$ (Table 3). The model also revealed significant gender interactions with $\ln$ hpcdd $(\mathrm{p}=0.0033)$ and $\ln$ DDT $(\mathrm{p}=0.0060)$ (Table 3). Ln Ocdd was positively associated with BMI increasing by 0.541 for every SD unit increase in ln Ocdd (Table 3). 
Table 3. Gender Interaction Regression Models for All Participants.

\begin{tabular}{|c|c|c|c|c|c|c|}
\hline \multirow[b]{2}{*}{ Variable } & \multicolumn{2}{|c|}{ BMI } & \multicolumn{2}{|c|}{ WC } & \multicolumn{2}{|c|}{ WC|BMI } \\
\hline & Beta & p-value & Beta & p-value & Beta & p-value \\
\hline Intercept & $\begin{array}{l}13.46 \\
(3.19)\end{array}$ & 0.0002 & $\begin{array}{l}52.91 \\
(9.37)\end{array}$ & $<0.00005$ & $\begin{array}{c}8.58 \\
(5.19)\end{array}$ & 0.1090 \\
\hline Mexican American & $\begin{array}{c}0.95 \\
(0.85)\end{array}$ & 0.2744 & $\begin{array}{c}1.78 \\
(2.33)\end{array}$ & 0.4514 & $\begin{array}{l}-0.39 \\
(0.77)\end{array}$ & 0.6143 \\
\hline Other Hispanic & $\begin{array}{c}1.43 \\
(1.04)\end{array}$ & 0.1792 & $\begin{array}{c}3.84 \\
(3.15)\end{array}$ & 0.2316 & $\begin{array}{l}-0.01 \\
(1.00)\end{array}$ & 0.9921 \\
\hline European American & $\begin{array}{c}0.54 \\
(0.81)\end{array}$ & 0.5068 & $\begin{array}{c}2.60 \\
(2.35)\end{array}$ & 0.2787 & $\begin{array}{c}1.67 \\
(0.89)\end{array}$ & 0.0711 \\
\hline African American & $\begin{array}{c}2.08 \\
(0.90)\end{array}$ & 0.0286 & $\begin{array}{c}3.39 \\
(2.39)\end{array}$ & 0.1674 & $\begin{array}{l}-1.15 \\
(0.88)\end{array}$ & 0.2019 \\
\hline Male & $\begin{array}{l}-0.97 \\
(5.27)\end{array}$ & 0.8550 & $\begin{array}{c}2.41 \\
(12.12)\end{array}$ & 0.8439 & $\begin{array}{c}3.90 \\
(4.36)\end{array}$ & 0.3782 \\
\hline Age & $\begin{array}{c}0.31 \\
(0.04)\end{array}$ & $<0.00005$ & $\begin{array}{c}0.86 \\
(0.10)\end{array}$ & $<0.00005$ & $\begin{array}{c}0.10 \\
(0.04)\end{array}$ & 0.0084 \\
\hline Age-2 & $\begin{array}{l}-0.003 \\
(0.005)\end{array}$ & $<0.00005$ & $\begin{array}{l}-0.01 \\
(.005)\end{array}$ & $<0.00005$ & $\begin{array}{c}0.00 \\
(0.005)\end{array}$ & 0.5574 \\
\hline BMI & . & . & . & . & $\begin{array}{c}3.31 \\
(0.21)\end{array}$ & $<0.00005$ \\
\hline BMI-2 & . & . & . & . & $\begin{array}{c}-0.02 \\
(0.005)\end{array}$ & 0.0001 \\
\hline $\ln ($ hpcdd) & $\begin{array}{l}-0.37 \\
(0.46)\end{array}$ & 0.4172 & $\begin{array}{l}-2.00 \\
(1.25)\end{array}$ & 0.1211 & $\begin{array}{l}-1.16 \\
(0.39)\end{array}$ & 0.0060 \\
\hline $\ln ($ Ocdd $)$ & $\begin{array}{c}1.23 \\
(0.44)\end{array}$ & 0.0091 & $\begin{array}{c}3.38 \\
(1.26)\end{array}$ & 0.0120 & $\begin{array}{c}0.50 \\
(0.46)\end{array}$ & 0.2839 \\
\hline $\ln$ (oxychlordane) & $\begin{array}{l}-0.21 \\
(0.88)\end{array}$ & 0.8135 & $\begin{array}{l}-0.51 \\
(2.26)\end{array}$ & 0.8235 & $\begin{array}{l}-0.29 \\
(0.78)\end{array}$ & 0.7081 \\
\hline ln(trans-nonachlor) & $\begin{array}{l}-0.55 \\
(0.80)\end{array}$ & 0.4971 & $\begin{array}{l}-1.49 \\
(2.01)\end{array}$ & 0.4650 & $\begin{array}{c}0.05 \\
(0.65)\end{array}$ & 0.9414 \\
\hline $\ln (\mathrm{DDT})$ & $\begin{array}{c}1.08 \\
(0.32)\end{array}$ & 0.0020 & $\begin{array}{c}2.73 \\
(0.75)\end{array}$ & 0.0010 & $\begin{array}{c}0.34 \\
(0.33)\end{array}$ & 0.3147 \\
\hline male* $\ln ($ hpcdd) & $\begin{array}{c}1.77 \\
(0.55)\end{array}$ & 0.0033 & $\begin{array}{c}4.85 \\
(1.63)\end{array}$ & 0.0059 & $\begin{array}{c}1.03 \\
(0.67)\end{array}$ & 0.1384 \\
\hline male* $\ln ($ Ocdd $)$ & $\begin{array}{l}-0.69 \\
(0.67)\end{array}$ & 0.3103 & $\begin{array}{l}-1.82 \\
(1.75)\end{array}$ & 0.3087 & $\begin{array}{l}-0.26 \\
(0.69)\end{array}$ & 0.7141 \\
\hline male* $\ln ($ oxychlordane) & $\begin{array}{c}1.68 \\
(0.96)\end{array}$ & 0.0896 & $\begin{array}{c}4.59 \\
(2.46)\end{array}$ & 0.0718 & $\begin{array}{c}1.03 \\
(0.82)\end{array}$ & 0.2229 \\
\hline male* $\ln$ (trans-nonachlor) & $\begin{array}{c}-0.47(0.80) \\
-1.24\end{array}$ & 0.5611 & $\begin{array}{l}-0.78 \\
(2.05)\end{array}$ & 0.7054 & $\begin{array}{l}-0.12 \\
(0.87)\end{array}$ & 0.8908 \\
\hline male* $\ln (\mathrm{DDT})$ & $(0.42)$ & 0.0060 & $\begin{array}{l}-3.97 \\
(0.97)\end{array}$ & 0.0003 & $\begin{array}{l}-1.04 \\
(0.35)\end{array}$ & 0.0056 \\
\hline $\begin{array}{l}\text { Joint Test p-value } \\
\text { R-Squared } \\
\mathrm{N}\end{array}$ & $\begin{array}{r}0.00 \\
0.09 \\
246\end{array}$ & & & & & $\begin{array}{l}550 \\
775 \\
28\end{array}$ \\
\hline
\end{tabular}

Note. WC stands for waist circumference. Numbers in parentheses are standard errors. Joint Test refers to the simultaneous test of all two-way gender by POPs interactions. 
For the ln hpcdd interaction, male BMIs increase by 0.413 and female BMIs decrease by 1.71 for every SD unit increase in ln hpcdd (Table 4). However, for the ln DDT interaction, male BMI decreases by 0.050 and female BMI increases by 0.344 for every SD unit increase of ln DDT (Table 4). The joint test p-value for simultaneously testing the interaction for the interaction BMI model is 0.0005 .

Table 4. Gender Interaction Equations for All Participants.

\begin{tabular}{|c|c|c|c|c|c|c|}
\hline \multirow[b]{2}{*}{ Variable } & \multicolumn{2}{|c|}{ BMI } & \multicolumn{2}{|c|}{ WC } & \multicolumn{2}{|c|}{ WC|BMI } \\
\hline & Male & Female & Male & Female & Male & Female \\
\hline Intercept & $\begin{array}{l}12.493 \\
(4.493)\end{array}$ & $\begin{array}{l}13.464 \\
(3.194)\end{array}$ & $\begin{array}{l}55.315 \\
(9.411)\end{array}$ & $\begin{array}{l}52.907 \\
(9.369)\end{array}$ & $\begin{array}{l}12.481 \\
(4.146)\end{array}$ & $\begin{array}{c}8.578 \\
(5.188)\end{array}$ \\
\hline Mexican American & $\begin{array}{c}0.948 \\
(0.851)\end{array}$ & $\begin{array}{c}0.948 \\
(0.851)\end{array}$ & $\begin{array}{l}17.780 \\
(2.331)\end{array}$ & $\begin{array}{c}1.779 \\
(2.331)\end{array}$ & $\begin{array}{l}-0.390 \\
(0.766)\end{array}$ & $\begin{array}{l}-0.390 \\
(0.766)\end{array}$ \\
\hline Other Hispanic & $\begin{array}{c}1.426 \\
(1.036)\end{array}$ & $\begin{array}{c}1.426 \\
(1.036)\end{array}$ & $\begin{array}{c}3.844 \\
(3.146)\end{array}$ & $\begin{array}{c}3.844 \\
(3.146)\end{array}$ & $\begin{array}{l}-0.010 \\
(1.000)\end{array}$ & $\begin{array}{l}-0.010 \\
(1.000)\end{array}$ \\
\hline European American & $\begin{array}{c}0.541 \\
(0.806)\end{array}$ & $\begin{array}{c}0.541 \\
(0.806)\end{array}$ & $\begin{array}{c}2.596 \\
(2.352)\end{array}$ & $\begin{array}{c}2.596 \\
(2.352)\end{array}$ & $\begin{array}{c}1.672 \\
(0.892)\end{array}$ & $\begin{array}{c}1.672 \\
(0.892)\end{array}$ \\
\hline African American & $\begin{array}{c}2.081 \\
(0.903)\end{array}$ & $\begin{array}{c}2.081 \\
(0.903)\end{array}$ & $\begin{array}{c}3.391 \\
(2.395)\end{array}$ & $\begin{array}{c}3.391 \\
(2.395)\end{array}$ & $\begin{array}{l}-1.145 \\
(0.877)\end{array}$ & $\begin{array}{l}-1.145 \\
(0.877)\end{array}$ \\
\hline Age & $\begin{array}{c}0.314 \\
(0.041)\end{array}$ & $\begin{array}{c}0.314 \\
(0.041)\end{array}$ & $\begin{array}{c}0.858 \\
(0.099)\end{array}$ & $\begin{array}{c}0.858 \\
(0.099)\end{array}$ & $\begin{array}{c}0.101 \\
(0.036)\end{array}$ & $\begin{array}{c}0.101 \\
(0.036)\end{array}$ \\
\hline Age-2 & $\begin{array}{l}-0.003 \\
(0.0004\end{array}$ & $\begin{array}{c}-0.003 \\
(0.0004)\end{array}$ & $\begin{array}{l}-0.007 \\
(0.001)\end{array}$ & $\begin{array}{l}-0.007 \\
(0.001)\end{array}$ & $\begin{array}{c}0.0002 \\
(0.0004)\end{array}$ & $\begin{array}{c}0.0002 \\
(0.0004)\end{array}$ \\
\hline BMI & $\begin{array}{l}\text { ) } \\
\text {. }\end{array}$ & & . & • & $\begin{array}{c}3.311 \\
(0.210)\end{array}$ & $\begin{array}{c}3.311 \\
(0.210)\end{array}$ \\
\hline BMI-2 & . & & . & . & $\begin{array}{c}-0.0165 \\
(0.003)\end{array}$ & $\begin{array}{c}-0.0165 \\
(0.003)\end{array}$ \\
\hline $\ln ($ hpcdd) & 1.391 & $\begin{array}{l}-0.375 \\
(0.455)\end{array}$ & $\begin{array}{c}2.849 \\
(0.809)\end{array}$ & $\begin{array}{c}-2.00 \\
(1.252)\end{array}$ & $\begin{array}{l}-0.132 \\
(0.434)\end{array}$ & $\begin{array}{l}-1.161 \\
(0.392)\end{array}$ \\
\hline $\ln ($ Ocdd $)$ & $\begin{array}{c}(0.297) \\
0.540\end{array}$ & $\begin{array}{c}1.230 \\
(0.440)\end{array}$ & $\begin{array}{c}1.559 \\
(1.091)\end{array}$ & $\begin{array}{c}3.77 \\
(1.259)\end{array}$ & $\begin{array}{c}0.243 \\
(0.391)\end{array}$ & $\begin{array}{c}0.499 \\
(0.457)\end{array}$ \\
\hline $\ln ($ oxychlordane) & $\begin{array}{c}(0.483) \\
1.471\end{array}$ & $\begin{array}{l}-0.209 \\
(0.878)\end{array}$ & $\begin{array}{c}4.084 \\
(1.651)\end{array}$ & $\begin{array}{l}-0.508 \\
(2.258)\end{array}$ & $\begin{array}{c}0.732 \\
(0.440)\end{array}$ & $\begin{array}{l}-0.293 \\
(0.776)\end{array}$ \\
\hline ln(trans-nonachlor) & $\begin{array}{c}(0.684) \\
-1.02\end{array}$ & $\begin{array}{l}-0.552 \\
(0.802)\end{array}$ & $\begin{array}{l}-2.270 \\
(1.635)\end{array}$ & $\begin{array}{l}-1.487 \\
(2.008)\end{array}$ & $\begin{array}{l}-0.072 \\
(0.432)\end{array}$ & $\begin{array}{c}0.048 \\
(0.647)\end{array}$ \\
\hline $\ln (\mathrm{DDT})$ & $\begin{array}{l}(0.630) \\
-0.163 \\
(0.307)\end{array}$ & $\begin{array}{c}1.081 \\
(0.318)\end{array}$ & $\begin{array}{l}-1.242 \\
(0.686)\end{array}$ & $\begin{array}{c}2.728 \\
(0.748)\end{array}$ & $\begin{array}{l}-0.704 \\
(0.170)\end{array}$ & $\begin{array}{c}0.337 \\
(0.329)\end{array}$ \\
\hline
\end{tabular}

Note. WC stands for waist circumference. Numbers in parentheses are standard errors.

The interaction WC model accounted for $18 \%$ of the WC variance and showed significant associations for $\ln$ Ocdd $(\mathrm{p}=0.0120)$ and $\ln$ DDT $(\mathrm{p}=0.0010)$ (Table 3). The model also showed significant gender interactions with $\ln$ hpcdd $(p=0.0059)$ and $\ln$ DDT $(p=0.0003)$ (Table 3). Similar to the previous model, WC increased by 4.259 centimeters for every SD unit increase in ln Ocdd (Table 3). Although the WC interaction was positive for ln hpcdd, male WC tended to increase 
by 2.305 centimeters whereas females decreased by 2.504 centimeters for every SD unit increase $\ln$ hpcdd (Table 4). For the ln DDT interaction, male BMI decreased by 0.852 while female BMI increased by 2.041 for every SD unit increase in ln DDT (Table 4). The joint test p-value for simultaneous testing for the interactions in the interaction WC model is $<0.00005$.

Lastly, the interaction WC model controlling for BMI accounted for $88 \%$ of the WC variance and showed significant associations for $\ln$ hpcdd $(\mathrm{p}=0.0060)$ with a significant gender by $\ln$ DDT interaction ( $\mathrm{p}=0.0056$ ) (Table 3). Not surprisingly, age and BMI were both positively associated with WC. However, as in the previous model, WC decreased by $0.452 \mathrm{~cm}$ for every SD unit increase in $\mathrm{ln}$ hpcdd (Table 3). The significant interaction shows that male WC decreases by $0.120 \mathrm{~cm}$ whereas female WC increases by $0.111 \mathrm{~cm}$ for every SD unit increase in ln DDT (Table 4). The joint test p-value for simultaneously testing for the interactions in the interaction WC model controlling for BMI is 0.0050 .

\subsection{Secondary (Sensitivity) Analysis}

\subsubsection{Additive Model}

Results of the additive regression models for participants with detectable POPs are presented in Table 5.

The additive BMI model accounted for $13 \%$ of the BMI variance and showed significant associations for ethnicity ( $p=0.0450)$, age $(p<0.00005)$, age squared $(p<0.00005)$, $\ln$ trans-nonachlor $(\mathrm{p}=0.0483)$, and $\ln \operatorname{DDT}(\mathrm{p}=0.0340)$ (Table 5). With the exception of $\ln$ trans-nonachlor, all of the effects were the same and in the same direction as in the primary additive BMI model. Here BMI decreases by 1.514 for every SD unit increase in ln trans-nonachlor (Table 5). The joint test for simultaneously testing the POPs was significant with $p=0.0017$. The model accounted for $2.8 \%$ of BMI.

For the additive WC model, significant associations, and in the same direction, for gender $(\mathrm{p}<0.00005)$, age $(\mathrm{p}<0.00005)$, and age squared $(\mathrm{p}<0.00005)$ appeared (Table 5$)$. However, unlike the additive WC model for all participants, ln Ocdd was not significant. The model accounted for $20 \%$ of the variance (Table 5). The joint test for simultaneously testing for the POPs was significant with ( $\mathrm{p}=0.0129)$.

For the additive WC model controlling for BMI, the model accounted for $87 \%$ of the WC variance (Table 5). With the exception of ln hpcdd, the same significant associations in the same direction were observed as with the model with all participants. Here, ln hpcdd was marginally significant ( $p=0.0527$ ), but it was still in the same direction. The joint test simultaneously testing all POPs was not significant. 
Table 5. Additive Regression Models for Participants with Detectable Persistent Organic Pollutants.

\begin{tabular}{|c|c|c|c|c|c|c|}
\hline \multirow[b]{2}{*}{ Variable } & \multicolumn{2}{|c|}{ BMI } & \multicolumn{2}{|c|}{ WC } & \multicolumn{2}{|c|}{ WC|BMI } \\
\hline & Beta & p-value & Beta & p-value & Beta & p-value \\
\hline Intercept & $\begin{array}{l}12.54 \\
(3.61)\end{array}$ & 0.0016 & $\begin{array}{l}53.02 \\
(8.35)\end{array}$ & $<0.00005$ & $\begin{array}{l}11.45 \\
(6.11)\end{array}$ & 0.0711 \\
\hline Mexican American & $\begin{array}{c}0.21 \\
(0.96)\end{array}$ & 0.8309 & $\begin{array}{l}-0.62 \\
(2.72)\end{array}$ & 0.8196 & $\begin{array}{l}-0.99 \\
(0.93)\end{array}$ & 0.2926 \\
\hline Other Hispanic & $\begin{array}{l}-0.13 \\
(1.25)\end{array}$ & 0.9146 & $\begin{array}{l}-1.63 \\
(3.38)\end{array}$ & 0.6329 & $\begin{array}{l}-1.11 \\
(1.11)\end{array}$ & 0.3234 \\
\hline European American & $\begin{array}{c}0.45 \\
(1.00)\end{array}$ & 0.6523 & $\begin{array}{c}1.11 \\
(2.84)\end{array}$ & 0.6990 & $\begin{array}{c}0.56 \\
(1.01)\end{array}$ & 0.5870 \\
\hline African American & $\begin{array}{c}2.43 \\
(1.16)\end{array}$ & 0.0450 & $\begin{array}{c}3.26 \\
(3.11)\end{array}$ & 0.3039 & $\begin{array}{l}-1.99 \\
(0.92)\end{array}$ & 0.0388 \\
\hline Male & $\begin{array}{c}0.35 \\
(0.36)\end{array}$ & 0.3361 & $\begin{array}{c}6.96 \\
(1.06)\end{array}$ & $<0.00005$ & $\begin{array}{c}5.85 \\
(0.45)\end{array}$ & $<0.00005$ \\
\hline Age & $\begin{array}{c}0.44 \\
(0.05)\end{array}$ & $<0.00005$ & $\begin{array}{c}1.15 \\
(0.12)\end{array}$ & $<0.00005$ & $\begin{array}{c}0.12 \\
(0.04)\end{array}$ & 0.0045 \\
\hline Age-2 & $\begin{array}{c}-0.00 \\
(0.005)\end{array}$ & $<0.00005$ & $\begin{array}{c}-0.01 \\
(0.005)\end{array}$ & $<0.00005$ & $\begin{array}{c}0.00 \\
(0.005)\end{array}$ & 0.8474 \\
\hline BMI & . & . & . & . & $\begin{array}{c}3.25 \\
(0.36)\end{array}$ & $<0.00005$ \\
\hline BMI-2 & . & . & . & . & $\begin{array}{l}-0.02 \\
(0.01)\end{array}$ & 0.0167 \\
\hline $\ln ($ hpcdd $)$ & $\begin{array}{c}0.62 \\
(0.43)\end{array}$ & 0.1554 & $\begin{array}{c}0.51 \\
(1.17)\end{array}$ & 0.6677 & $\begin{array}{l}-0.77 \\
(0.38)\end{array}$ & 0.0527 \\
\hline $\ln ($ Ocdd) & $\begin{array}{c}0.62 \\
(0.40)\end{array}$ & 0.1344 & $\begin{array}{c}1.69 \\
(0.94)\end{array}$ & 0.0843 & $\begin{array}{c}0.13 \\
(0.30)\end{array}$ & 0.6732 \\
\hline $\ln$ (oxychlordane) & $\begin{array}{c}1.56 \\
(0.91)\end{array}$ & 0.0979 & $\begin{array}{c}3.91 \\
(2.41)\end{array}$ & 0.1147 & $\begin{array}{c}0.08 \\
(1.06)\end{array}$ & 0.9401 \\
\hline ln(trans-nonachlor) & $\begin{array}{l}-1.76 \\
(0.86)\end{array}$ & 0.0483 & $\begin{array}{l}-3.94 \\
(2.28)\end{array}$ & 0.0940 & $\begin{array}{c}0.26 \\
(0.68)\end{array}$ & 0.7114 \\
\hline $\ln (\mathrm{DDT})$ & $\begin{array}{c}0.55 \\
(0.25) \\
\end{array}$ & 0.0340 & $\begin{array}{c}0.98 \\
(0.53) \\
\end{array}$ & 0.0736 & $\begin{array}{l}-0.14 \\
(0.24)\end{array}$ & 0.5575 \\
\hline $\begin{array}{l}\text { Joint Test p-value } \\
\text { R-Squared } \\
\text { R-Squared (No POPs) } \\
\mathrm{N}\end{array}$ & $\begin{array}{l}0 \\
0 \\
0 \\
1\end{array}$ & & & & & $\begin{array}{l}207 \\
736 \\
727 \\
996\end{array}$ \\
\hline
\end{tabular}

Note. WC stands for waist circumference. Numbers in parentheses are standard errors. Joint Test refers to the simultaneous test of all POPs.

\subsubsection{Interaction Models}

Table 6 displays the results of the interaction regression models for participants with detectable POPs, and Table 7 displays the interaction regression equations for males and females. The interaction BMI model accounted for $15 \%$ of the variance and showed the same significant associations for 
age ( $p<0.00005)$, age squared ( $<$ 0.00005), ln Ocdd ( $p=0.0277)$, and ln DDT ( $p=0.0340)$ (Table 6). However, here there were no significant gender interactions with ln hpcdd or ln DDT. Instead, there was a gender interaction with ln oxychlordane $(p=0.0204)$ (Table 6). Further, inspection of the interactions through Table 7 shows that male BMI increases by 3.483 and female BMI decreases by 0.323 for every SD unit increase in ln oxychlordane (Table 7). The simultaneous test for the gender by POPs interactions was significant with $\mathrm{p}=0.0121$.

Table 6. Gender Interaction Regression Models for Detectable Persistent Organic Pollutants.

\begin{tabular}{|c|c|c|c|c|c|c|}
\hline & \multicolumn{2}{|c|}{ BMI } & \multicolumn{2}{|c|}{ WC } & \multicolumn{2}{|c|}{ WC|BMI } \\
\hline Variable & Beta & p-value & Beta & p-value & Beta & $\mathrm{p}$-value \\
\hline Intercept & $\begin{array}{c}6.53 \\
(4.57)\end{array}$ & 0.1637 & $\begin{array}{c}39.17 \\
(10.98)\end{array}$ & 0.0013 & $\begin{array}{l}10.60 \\
(7.06)\end{array}$ & 0.1440 \\
\hline Mexican American & $\begin{array}{c}0.21 \\
(0.94)\end{array}$ & 0.8204 & $\begin{array}{l}-0.54 \\
(2.60)\end{array}$ & 0.8371 & $\begin{array}{l}-0.94 \\
(0.94)\end{array}$ & 0.3258 \\
\hline Other Hispanic & $\begin{array}{l}-0.23 \\
(1.24)\end{array}$ & 0.8539 & $\begin{array}{l}-1.85 \\
(3.30)\end{array}$ & 0.5788 & $\begin{array}{l}-0.10 \\
(1.12)\end{array}$ & 0.3329 \\
\hline European American & $\begin{array}{c}0.38 \\
(0.95)\end{array}$ & 0.6932 & $\begin{array}{c}0.91 \\
(2.68)\end{array}$ & 0.7380 & $\begin{array}{c}0.49 \\
(1.01)\end{array}$ & 0.6314 \\
\hline African American & $\begin{array}{c}2.28 \\
(1.14)\end{array}$ & 0.0550 & $\begin{array}{c}2.81 \\
(2.99)\end{array}$ & 0.3553 & $\begin{array}{l}-2.06 \\
(0.90)\end{array}$ & 0.0299 \\
\hline Male & $\begin{array}{l}12.35 \\
(5.50)\end{array}$ & 0.3250 & $\begin{array}{c}34.31 \\
(12.66)\end{array}$ & 0.0112 & $\begin{array}{c}8.37 \\
(5.68)\end{array}$ & 0.1513 \\
\hline Age & $\begin{array}{c}0.42 \\
(0.05)\end{array}$ & $<0.00005$ & $\begin{array}{c}1.10 \\
(0.12)\end{array}$ & $<0.00005$ & $\begin{array}{c}0.11 \\
(0.04)\end{array}$ & 0.0105 \\
\hline Age-2 & $\begin{array}{c}-0.00 \\
(0.005)\end{array}$ & $<0.00005$ & $\begin{array}{c}-0.01 \\
(0.005)\end{array}$ & $<0.00005$ & $\begin{array}{c}0.00 \\
(0.005)\end{array}$ & 0.6216 \\
\hline BMI & . & . & . & . & $\begin{array}{c}3.21 \\
(0.37)\end{array}$ & $<0.00005$ \\
\hline BMI-2 & . & . & . & . & $\begin{array}{l}-0.02 \\
(0.01)\end{array}$ & 0.0211 \\
\hline $\ln ($ hpcdd $)$ & $\begin{array}{c}0.18 \\
(0.65)\end{array}$ & 0.7877 & $\begin{array}{l}-1.18 \\
(1.87)\end{array}$ & 0.5323 & $\begin{array}{c}-1.49 \\
(0.61)\end{array}$ & 0.0214 \\
\hline $\ln ($ Ocdd $)$ & $\begin{array}{c}1.42 \\
(0.61)\end{array}$ & 0.0277 & $\begin{array}{c}3.84 \\
(1.58)\end{array}$ & 0.0213 & $\begin{array}{c}0.58 \\
(0.48)\end{array}$ & 0.2329 \\
\hline $\ln$ (oxychlordane) & $\begin{array}{l}-0.24 \\
(1.37)\end{array}$ & 0.8638 & $\begin{array}{l}-1.04 \\
(3.64)\end{array}$ & 0.7770 & $\begin{array}{l}-1.26 \\
(1.43)\end{array}$ & 0.3847 \\
\hline $\ln$ (trans-nonachlor) & $\begin{array}{l}-1.21 \\
(1.18)\end{array}$ & 0.3148 & $\begin{array}{l}-2.47 \\
(3.21)\end{array}$ & 0.4480 & $\begin{array}{c}0.88 \\
(1.18)\end{array}$ & 0.4614 \\
\hline $\ln (\mathrm{DDT})$ & $\begin{array}{c}0.98 \\
(0.44)\end{array}$ & 0.0340 & $\begin{array}{c}2.38 \\
(0.95)\end{array}$ & 0.0184 & $\begin{array}{c}0.17 \\
(0.37)\end{array}$ & 0.6565 \\
\hline male* $\ln ($ hpcdd) & $\begin{array}{c}0.96 \\
(0.76)\end{array}$ & 0.2172 & $\begin{array}{c}3.83 \\
(2.34)\end{array}$ & 0.1129 & $\begin{array}{c}1.80 \\
(0.78)\end{array}$ & 0.0283 \\
\hline male* $\ln ($ Ocdd $)$ & $\begin{array}{l}-1.55 \\
(0.80)\end{array}$ & 0.0637 & $\begin{array}{l}-4.18 \\
(2.21)\end{array}$ & 0.0681 & $\begin{array}{l}-0.89 \\
(0.85)\end{array}$ & 0.3067 \\
\hline male* $\ln ($ oxychlordane $)$ & $\begin{array}{c}3.74 \\
(1.52)\end{array}$ & 0.0204 & $\begin{array}{l}10.43 \\
(3.89)\end{array}$ & 0.0119 & $\begin{array}{c}2.94 \\
(1.23)\end{array}$ & 0.0231 \\
\hline male* $\ln$ (trans-nonachlor) & $\begin{array}{l}-1.34 \\
(1.06)\end{array}$ & 0.3316 & $\begin{array}{l}-3.68 \\
(3.51)\end{array}$ & 0.3037 & $\begin{array}{l}-1.55 \\
(1.30)\end{array}$ & 0.2423 \\
\hline male* $\ln (\mathrm{DDT})$ & $\begin{array}{l}-0.83 \\
(0.56)\end{array}$ & 0.1503 & $\begin{array}{l}-2.65 \\
(1.24)\end{array}$ & 0.0409 & $\begin{array}{l}-0.53 \\
(0.43)\end{array}$ & 0.2285 \\
\hline
\end{tabular}


Table 6. Cont.

\begin{tabular}{l|c|c|c}
\hline Joint Test p-value & 0.0121 & 0.0011 & 0.0012 \\
R-Squared & 0.1480 & 0.2259 & 0.8757 \\
$\mathrm{~N}$ & 1727 & 1709 & 1696 \\
\hline
\end{tabular}

Note. WC stands for waist circumference. Numbers in parentheses are standard errors. Joint Test refers to the simultaneous test of all two-way gender by POPs interactions.

The interaction WC model accounted for $23 \%$ of the variance and showed significant associations for gender ( $\mathrm{p}=0.0112)$, age $(\mathrm{p}<0.00005)$, age squared $(\mathrm{p}<0.00005)$, ln Ocdd $(\mathrm{p}=0.0123)$, and $\ln$ DDT ( $p=0.0184)$ (Table 6). The significant associations were in the same direction as the interaction WC model with all participants. The model also showed significant gender interactions with $\ln$ oxychlordane $(p=0.0119)$ and DDT $(p=0.0409)$ (Table 6$)$. The gender by ln hpcdd was not significant in this model. The gender by ln oxychlordane interaction was in the same direction as the primary WC model. Table 7 shows that for the gender by ln Ocdd interaction male WC decreases by 0.398 and female BMI increases by 6.054 for every SD unit increase in ln Ocdd. The gender by DDT interaction indicates that male WC decreases by 0.193 and female WC increases by 2.260 for every SD unit increase in DDT. The joint test for simultaneously testing for the gender by POPs interactions was significant with $(\mathrm{p}=0.0011)$.

Finally, the interaction WC model controlling for BMI accounted for $88 \%$ of the WC variance with significant main associations for ethnicity $(\mathrm{p}=0.0299)$, age $(\mathrm{p}=0.0105)$, BMI $(\mathrm{p}<0.00005)$, BMI squared ( $p=0.0211)$, and ln hpcdd $(\mathrm{p}=0.0214)$ (Table 6$)$. The ethnicity main effect was the only difference in main effects between the current model and primary WC conditional on BMI model. Even so, it appears that African Americans have 2.05 lower WC than other races. With regard to interactions, there are significant gender-by-ln hpcdd ( $p=0.0283)$, and gender-by-ln oxychlordane $(p=0.0231$ ) interactions (Table 6). The gender-by-ln DDT interaction was not significant here. Inspection of Table 7 shows that male BMI increases by 0.129 and female BMI decreases by 0.917 for every SD unit increase in ln hpcdd. However, male BMI increases by 1.577 whereas female BMI decreases by 1.793 for every SD unit increase in ln oxychlordane (Table 7). The joint test for simultaneously testing the gender-by- POPs interactions was significant with $\mathrm{p}=0.0012$.

Table 7. Gender interaction equations for detectable persistent organic pollutants.

\begin{tabular}{l|cc|cc|cc}
\hline & \multicolumn{2}{|c|}{ BMI } & \multicolumn{2}{c|}{ WC } & \multicolumn{2}{c}{ WC|BMI } \\
\hline Variable & Male & Female & Male & Female & Male & Female \\
\hline Intercept & 18.877 & 6.530 & 73.476 & 39.167 & 18.966 & 10.596 \\
& $(4.107)$ & $(4.569)$ & $(8.789)$ & $(10.985)$ & $(6.742)$ & $(7.056)$ \\
Mexican American & 0.214 & 0.214 & -0.540 & -0.540 & -0.941 & -0.941 \\
& $(0.936)$ & $(0.936)$ & $(2.602)$ & $(2.602)$ & $(0.942)$ & $(0.942)$ \\
Other Hispanic & -0.230 & -0.230 & -1.850 & -1.850 & -1.105 & -1.105 \\
& $(1.237)$ & $(1.237)$ & $(3.295)$ & $(3.295)$ & $(1.122)$ & $(1.122)$ \\
European American & 0.379 & 0.379 & 0.905 & 0.905 & 0.488 & 0.486 \\
& $(0.951)$ & $(0.951)$ & $(2.680)$ & $(2.680)$ & $(1.006)$ & $(1.006)$ \\
African American & 2.282 & 2.282 & 2.810 & 2.810 & -2.061 & -2.061 \\
& $(1.141)$ & $(1.141)$ & $(2.991)$ & $(2.991)$ & $(0.902)$ & $(0.902)$ \\
\hline
\end{tabular}


Table 7. Cont.

\begin{tabular}{l|cc|cc|cc}
\hline Age & 0.423 & 0.423 & 1.095 & 1.095 & 0.002 & 0.112 \\
Age-2 & $(0.050)$ & $(0.050)$ & $(0.118)$ & $(0.118)$ & $(0.041)$ & $(0.041)$ \\
& -0.004 & -0.004 & -0.009 & -0.009 & 0.0002 & 0.0002 \\
BMI & $(0.0005)$ & $(0.0005)$ & $(0.001)$ & $(0.001)$ & $(0.0005)$ & $(0.0005)$ \\
& $\cdot$ &. &. &. & 3.205 & 3.205 \\
BMI-2 & & & & & $(0.369)$ & $(0.369)$ \\
& $\cdot$ &. &. &. & -0.0152 & -0.015 \\
$\ln ($ hpcdd) & & & & & $(0.006)$ & $(0.006)$ \\
& 1.134 & 0.176 & 2.654 & -1.179 & 0.305 & -1.493 \\
$\ln$ (Ocdd) & $(0.423)$ & $(0.647)$ & $(1.207)$ & $(1.865)$ & $(0.423)$ & $(0.614)$ \\
$\ln$ (oxychlordane) & -0.129 & 1.418 & -0.342 & 3.839 & -0.302 & 0.585 \\
& $(0.481)$ & $(0.611)$ & $(1.164)$ & $(1.577)$ & $(0.588)$ & $(0.480)$ \\
$\ln$ (trans-nonachlor) & 3.504 & -0.236 & 9.392 & -1.042 & 1.683 & -1.258 \\
& $(0.994)$ & $(1.367)$ & $(2.443)$ & $(3.645)$ & $(0.937)$ & $(1.425)$ \\
$\ln$ (DDT) & -2.550 & -1.212 & -6.152 & -2.473 & -0.665 & 0.880 \\
& $(0.991)$ & $(1.185)$ & $(2.439)$ & $(3.215)$ & $(0.581)$ & $(1.179)$ \\
& 0.154 & 0.982 & -0.278 & 2.377 & -0.366 & 0.165 \\
& $(0.324)$ & $(0.441)$ & $(0.699)$ & $(0.951)$ & $(0.215)$ & $(0.368)$ \\
\hline
\end{tabular}

Note. WC stands for waist circumference. Numbers in parentheses are standard errors.

\subsubsection{Comparison of All Participants and Participants with Detectable POPs Models}

Consistent findings for the additive models with all participant and participants with detectable POPs were as follows: The additive BMI models showed consistent associations for ethnicity, age, age squared, and ln DDT. For the additive WC model, the consistent associations were for gender, age, and ln Ocdd. Lastly, the additive WC model controlling for BMI show consistent finding for gender, age, BMI, and BMI squared.

Consistent findings for the interaction models for all participants and participants with detectable POPs were as follows: The interaction BMI model showed consistent associations for age, age squared, and ln Ocdd. The interaction WC model showed consistent associations for age, ln Ocdd, and ln DDT. In addition, it had consistent gender by ln oxychlordane and ln DDT interactions. Lastly, the interaction WC model controlling for BMI had consistent associations for age, BMI, BMI squared, and ln hpcdd.

Lastly, the additive and interaction models were estimated with all participants ages 19 and up (results not shown but available upon request). Results of these analyses were consistent with the results of the equivalent models with all participants. Specifically, all parameter estimates were in the same directions and those that were significant (or not significant) remained significant (or not significant). The one exception occurred with the interaction model of waist circumference controlling for BMI. In this model the parameter estimate for European Americans went from non significant to significant and the parameter estimate for age went from significant to non significant. 


\section{Conclusions}

Consistent effects were found for Ocdd and/or DDT with BMI. In addition, a relatively consistent association between WC and hpcdd controlling for BMI was found. To the extent that our associations can be speculated to represent causation, on average, one of the toxic effects of these chemicals appears to be weight gain. Unlike the well-known weight loss resulting from high exposure to POPs, this weight gain may occur at much lower levels of exposure, levels which fail to make animals or humans obviously ill [21]. A couple opposite gender effects was also identified. Oxychlordane is associated with BMI increases in males but a BMI decreases in females (Tables 6 and 7). Conversely, DTT is associated with WC decreases in males but WC increases in females (Table 4). A speculation, which needs further validation, is that this might have to do with hormonally-directed differences in fat storage in men versus women. Men tend to be "apples" and store their fat in the waist, whereas females tend to be "pears" and store their fat in their hips. POPs might be affecting this process.

Because of their previous extensive usage as pesticides, their inherent structural stability, their persistence in body systems and their ability to concentrate in animals that are higher up on the food chain, many POPs are currently present in human fat in relatively high levels. Much of any chemicalinduced weight gain may come from increases in the overall proportion of body fat. In one animal study, the pesticide dieldrin more than doubled the total body-fat content of treated mice [22]. Another study showed that a pesticide, commonly known as lindane, induced obesity in animals [23]. In yet another study, the overall weight gain effect of another pesticide, hexachlorobenzene, appeared to be so powerful that a group of treated animals still managed to gain significantly more weight despite the fact that their food intake was cut by $50 \%$ relative to untreated controls that were on full food rations [24].

Persistent organic pollutants, synthetic and industrial chemicals, appear to cause weight gain by interfering with most of the different elements that comprise the human weight control system. In particular, these chemicals have been shown to disrupt major weight controlling hormones, such as thyroid hormones, estrogens, testosterone, corticosteroids, insulin, growth hormone, and leptin [25] and to alter levels of, and sensitivity to, neurotransmitters (in particular dopamine, noradrenaline, and serotonin [26]. They interfere with many metabolic processes and cause widespread damage to body tissues and cardiovascular disease [27]. This interference may result in changes in appetite, in food efficiency, and in fat, carbohydrate, and protein metabolism. The desire, and ability, to exercise also may be affected. These changes have been thought to be responsible for increases in body weight $[21,23,28,29]$.

What are the contributions of POPs to pre-diabetes and diabetes disorders? Lee and colleagues have recently shown a dose-response relation between serum concentrations of POPs and metabolic syndrome [17], insulin resistance [18], and diabetes [19]. They claimed that the expected association between obesity and diabetes was absent with people with low concentrations of POPs [19]. However, Porta argues that the adjustment for BMI and WC in the published studies might be an over adjustment, because dietary fats are a major source of POPs [36].

These investigators determined that POPs have a much greater association with these diseases in obese people compared with non-obese people. They hypothesize that the toxicity of POPs related to the risk of metabolic syndrome, insulin resistance, and diabetes substantially increases as people get 
more obese [17]. However, another possibility is that POPs, in addition to their contribution to metabolic syndrome, insulin resistance, and diabetes, might also directly contribute to obesity. The complex interactions among POPs, obesity, and diabetes-related disorders make the determination of the contribution of a single component difficult. Long-term longitudinal cohort studies with repeated measurements of BMI, WC, and POPs levels and continued model organism experimentation could help solve this problem.

Are environmental chemicals responsible for the obesity epidemic? Keith and colleagues coined the phrase "The Big Two" to refer to two commonly presumed causes of the obesity epidemic, namely food marketing practices and institutionally-driven reductions in physical activity [30]. The Big Two are likely contributors, but there are several other likely contributors, such as POPs [30]. The particular POPs studied herein were chosen in this study because they are present in over $80 \%$ of the NHANES population. However, the concentrations of some POPs in general have been decreasing in the past two decades in the U.S. population because of stricter regulation [31], whereas obesity has been increasing during this same period. According to NHANES data, obesity (i.e., BMI $\geq 30$ ) has increased from almost $30 \%$ of the adult population in 1980 to over $60 \%$ of the population in 2000 [31]. How then can we explain the strong dose-response relation between serum concentrations of POPs and obesity? A possibility is that the effects of the POPs were on neonates 20 years ago, and that this is only now becoming manifest in the adult population. This theory is called the "developmental origins of health and disease" (DOHaD), or the "Barker hypothesis," because it was first proposed by Barker and colleagues [32].

An excellent example of $\mathrm{DOHaD}$ that is related to POPs and obesity is recent work done by Retha Newbold and colleagues [16,33]. In pioneering work started in the 1970s, Dr. Newbold and colleagues showed that the potent estrogenic compound diethylstilbesterol (DES) can increase the incidence of uterine cancer and testicular atrophy in the children and grandchildren of pregnant mothers given this compound, which was used in humans to treat morning sickness [34,35]. In recent studies, they showed that low doses of DES $(0.001 \mathrm{mg} / \mathrm{kg})$ given every day for the first 5 days after birth can induce obesity in post-pubertal mice [16,33]. Whether a similar phenomenon occurs in humans will be the subject of future investigations.

\section{Acknowledgements}

This work was supported in part by T32HL007457, P30DK056336, \& R01AR052658 at the University of Alabama at Birmingham and by the Environmental Health Sciences Center in Molecular and Cellular Toxicology with Human Applications Grant P30 ES06639 at Wayne State University, and NIH R01 grants (ES012933 and CA105349) to D.M.R. David B. Allison has received consulting fees, donations, honoraria, royalties, and grants from numerous for-profit and not-for-profit entities with interests in obesity, including companies and litigators interested in effects of environmental toxins on obesity. 


\section{References and Notes}

1. Ogden, C.L.; Flegal, K.M.; Carroll, M.D.; Johnson, C.L. Prevalence and trends in overweight among US children and adolescents, 1999-2000. JAMA 2002, 288, 1728-1732.

2. Folsom, A.R.; Kaye, S.A.; Sellers, T.A.; Hong, C.P.; Cerhan, J.R.; Potter, J.D.; Prineas, R.J., Body fat distribution and 5-year risk of death in older women. JAMA 1993, 269, 483-487.

3. Janssen, I.; Katzmarzyk, P.T.; Ross, R. Body mass index, waist circumference, and health risk: evidence in support of current National Institutes of Health guidelines. Arch. Intern. Med. 2002, 162, 2074-2079.

4. Rimm, E.B.; Stampfer, M.J.; Giovannucci, E.; Ascherio, A.; Spiegelman, D.; Colditz, G.A.; Willett, W.C. Body size and fat distribution as predictors of coronary heart disease among middleaged and older US men. Am. J. Epidemiol. 1995, 141, 1117-1127.

5. Seidell, J.C.; Bjorntorp, P.; Sjostrom, L.; Sannerstedt, R.; Krotkiewski, M.; Kvist, H. Regional distribution of muscle and fat mass in men-new insight into the risk of abdominal obesity using computed tomography. Int. J. Obes. 1989, 13, 289-303.

6. Willett, W.C.; Manson, J.E.; Stampfer, M.J.; Colditz, G.A.; Rosner, B.; Speizer, F.E.; Hennekens, C.H. Weight, weight change, and coronary heart disease in women. Risk within the 'normal' weight range. JAMA 1995, 273, 461-465.

7. Despres, J.P., Abdominal obesity as important component of insulin-resistance syndrome. Nutrition 1993, 9, 452-459.

8. Haffner, S.M.; Valdez, R.A.; Hazuda, H.P.; Mitchell, B.D.; Morales, P.A.; Stern, M.P. Prospective analysis of the insulin-resistance syndrome (syndrome X). Diabetes 1992, 41, 715-722.

9. Ivandic, A.; Prpic-Krizevac, I.; Bozic, D.; Barbir, A.; Peljhan, V.; Balog, Z.; Glasnovic, M. Insulin resistance and androgens in healthy women with different body fat distributions. Wien. Klin. Wochenschr. 2002, 114, 321-326.

10. Ross, R.; Freeman, J.; Hudson, R.; Janssen, I. Abdominal obesity, muscle composition, and insulin resistance in premenopausal women. J .Clin. Endocrinol. Metab. 2002, 87, 5044-5051.

11. Le Marchand, L.; Wilkens, L.R.; Mi, M.P. Obesity in youth and middle age and risk of colorectal cancer in men. Cancer Cause. Control 1992, 3, 349-354.

12. Moyad, M.A. Obesity, interrelated mechanisms, and exposures and kidney cancer. Semin. Urol. Oncol. 2001, 19, 270-279.

13. Stoll, B.A. Upper abdominal obesity, insulin resistance and breast cancer risk. Int. J. Obes. Relat. Metab. Disord. 2002, 26, 747-753.

14. Elobeid, M.A.; Desmond, R.A.; Thomas, O.; Keith, S.W.; Allison, D.B. Waist circumference values are increasing beyond those expected from BMI increases. Obesity (Silver Spring) 2007, 15, 2380-2383.

15. Heindel, J.J. Endocrine disruptors and the obesity epidemic. Toxicol. Sci. 2003, 76, 247-249.

16. Newbold, R.R.; Padilla-Banks, E.; Jefferson, W.N.; Heindel, J.J. Effects of endocrine disruptors on obesity. Int. J. Androl. 2008, 31, 201-208. 
17. Lee, D.H.; Lee, I.K.; Porta, M.; Steffes, M.; Jacobs, D.R., Jr. Relationship between serum concentrations of persistent organic pollutants and the prevalence of metabolic syndrome among non-diabetic adults: results from the National Health and Nutrition Examination Survey 19992002. Diabetologia 2007, 50, 1841-1851.

18. Lee, D.H.; Lee, I.K.; Jin, S.H.; Steffes, M.; Jacobs, D.R., Jr. Association between serum concentrations of persistent organic pollutants and insulin resistance among nondiabetic adults: results from the National Health and Nutrition Examination Survey 1999-2002. Diabetes Care 2007, 30, 622-628.

19. Lee, D.H.; Lee, I.K.; Song, K.; Steffes, M.; Toscano, W.; Baker, B.A.; Jacobs, D.R., Jr. A strong dose-response relation between serum concentrations of persistent organic pollutants and diabetes: results from the National Health and Examination Survey 1999-2002. Diabetes Care 2006, 29, 1638-1644.

20. Dioxins. Available online: http://toxics.usgs.gov/definitions/dioxins.html/ (accessed on 16 July 2010).

21. Takahama, K.; Ishii, Y.; Kanda, M. Toxicological studies on organochlorine pesticides. 1. Effects of long term administration of organochlorine pesticides on rabbit body weight and organ weight. Nihon Hoigaku Zasshi 1972, 26, 5-10.

22. Deichmann, W.B.; MacDonald, W.E.; Cubit, D.A.; Beasley, A.G. Effects of starvation in rats with elevated DDT and dieldrin tissue levels. Int. Arch. Arbeitsmed. 1972, 29, 233-252.

23. Chadwick, R.W.; Cooper, R.L.; Chang, J.; Rehnberg, G.L.; McElroy, W.K., Possible antiestrogenic activity of lindane in female rats. J .Biochem. Toxicol. 1988, 3, 147-158.

24. Villeneuve, D.C.; van Logten, M.J.; den Tonkelaar, E.M.; Greve, P.A.; Vos, J.G.; Speijers, G.J.; van Esch, G.J. Effect of food deprivation on low level hexachlorobenzene exposure in rats. Sci. Total Environ. 1977, 8, 179-186.

25. Yamagishi, S.I.; Edelstein, D.; Du, X.L.; Kaneda, Y.; Guzman, M.; Brownlee, M. Leptin induces mitochondrial superoxide production and monocyte chemoattractant protein-1 expression in aortic endothelial cells by increasing fatty acid oxidation via protein kinase A. $J$. Biol. Chem. 2001, 276, 25096-25100.

26. Mariussen, E.; Fonnum, F. Neurochemical targets and behavioral effects of organohalogen compounds: an update. Crit. Rev. Toxicol. 2006, 36, 253-289.

27. Humblet, O.; Birnbaum, L.; Rimm, E.; Mittleman, M.A.; Hauser, R. Dioxins and cardiovascular disease mortality. Environ. Health Perspect. 2008, 116, 1443-1448.

28. Gupta, B.N.; McConnell, E.E.; Goldstein, J.A.; Harris, M.W.; Moore, J.A. Effects of a polybrominated biphenyl mixture in the rat and mouse. I. Six-month exposure. Toxicol. Appl. Pharmacol. 1983, 68, 1-18.

29. Trankina, M.L.; Beitz, D.C.; Trenkle, A.H. Effects of in vitro ronnel on metabolic activity in subcutaneous adipose tissue and skeletal muscle from steers. J. Anim. Sci. 1985, 60, 652-658. 
30. Keith, S.W.; Redden, D.T.; Katzmarzyk, P.T.; Boggiano, M.M.; Hanlon, E.C.; Benca, R.M.; Ruden, D.; Pietrobelli, A.; Barger, J.L.; Fontaine, K.R.; Wang, C.; Aronne, L.J.; Wright, S.M.; Baskin, M.; Dhurandhar, N.V.; Lijoi, M.C.; Grilo, C.M.; DeLuca, M.; Westfall, A.O.; Allison, D.B. Putative contributors to the secular increase in obesity: exploring the roads less traveled. Int. J. Obes. (Lond) 2006, 30, 1585-1594.

31. Needham, L.L.; Barr, D.B.; Caudill, S.P.; Pirkle, J.L.; Turner, W.E.; Osterloh, J.; Jones, R.L.; Sampson, E.J. Concentrations of environmental chemicals associated with neurodevelopmental effects in U.S. population. Neurotoxicology 2005, 26, 531-545.

32. Barker, D.J.; Eriksson, J.G.; Forsen, T.; Osmond, C. Fetal origins of adult disease: strength of effects and biological basis. Int. J. Epidemiol. 2002, 31, 1235-1239.

33. Newbold, R.R.; Padilla-Banks, E.; Snyder, R.J.; Phillips, T.M.; Jefferson, W.N. Developmental exposure to endocrine disruptors and the obesity epidemic. Reprod. Toxicol. 2007, 23, 290-296.

34. Newbold, R.R.; Padilla-Banks, E.; Jefferson, W.N. Adverse effects of the model environmental estrogen diethylstilbestrol are transmitted to subsequent generations. Endocrinology 2006, 147, S11-S17.

35. Ruden, D.M.; Xiao, L.; Garfinkel, M.D.; Lu, X. Hsp90 and environmental impacts on epigenetic states: a model for the trans-generational effects of diethylstibesterol on uterine development and cancer. Hum. Mol. Genet. 2005, 14, R149-R155.

36. Porta, M. Persistent organic pollutants and the burden of diabetes. Lancet 2006, 368, 558-559.

(C) 2010 by the authors; licensee MDPI, Basel, Switzerland. This article is an Open Access article distributed under the terms and conditions of the Creative Commons Attribution license (http://creativecommons.org/licenses/by/3.0/). 